\title{
Photochemical reactivity of aquatic macrophyte leachates: abiotic transformations and bacterial response
}

\author{
Vinicius F. Farjalla ${ }^{1}$, Alexandre M. Anesio ${ }^{2, *}$, Stefan Bertilsson ${ }^{3}$, Wilhelm Granéli ${ }^{2}$ \\ ${ }^{1}$ Department of Ecology, Federal University of Rio de Janeiro, 21941-590, Brazil \\ ${ }^{2}$ Department of Ecology/Limnology, Lund University, 22362 Lund, Sweden \\ ${ }^{3}$ Department of Civil and Environmental Engineering, Massachusetts Institute of Technology, Cambridge, \\ Massachusetts 02139, USA
}

\begin{abstract}
We evaluated the influence of UV radiation exposure time on abiotic transformations of leachates from 2 aquatic macrophytes: Phragmites australis and Hydrocaris morsus-ranae. In addition, we studied the influence of phototransformations of DOM on bacterial growth. Sterile filtered leachates were exposed to UV radiation for 5, 10, 24, 48, 72 and $120 \mathrm{~h}$ or kept in the dark. Dissolved inorganic carbon (DIC), hydrogen peroxide and low molecular weight carboxylic acids (oxalic, formic, malonic and acetic acids) were measured. After UV or dark treatment, the leachates were inoculated with bacteria and incubated in the dark. Based on the observed DIC and hydrogen peroxide formation rates, we concluded that phototransformations are initially more rapid in $H$. morsusranae DOM than in P. australis DOM. On the other hand, production of DIC after more than $48 \mathrm{~h}$ of UV exposure was strongly reduced for $H$. morsus-ranae DOM, whereas DIC production was only slightly reduced for $P$. australis DOM. The differences in the photoreactivity between DOM from $P$. australis and $H$. morsus-ranae DOM were also reflected in the bacterial growth response to DOM phototransformations. The lowest bacterial growth efficiencies (BGE) were found in the irradiated leachate of $P$. australis exposed for more than $48 \mathrm{~h}$ and in the irradiated leachate of $H$. morsus-ranae exposed for $10 \mathrm{~h}$, which coincided with the highest concentrations of hydrogen peroxide for both types of leachates.
\end{abstract}

KEY WORDS: UV radiation $\cdot$ Macrophyte leachate $\cdot$ Bacteria $\cdot$ Bioavailability $\cdot$ Hydrogen peroxide $\cdot$ Mineralization Resale or republication not permitted without written consent of the publisher

\section{INTRODUCTION}

One of the largest fluxes of carbon, in almost any ecosystem, is that from the pool of organic matter into microorganisms, which subsequently respire a large part of the substrate (Cole 1999). Recently, solar radiation has been recognized as a significant cause of mineralization of dissolved organic matter (DOM) in surface waters (Granéli et al. 1996). Thus, photooxidation

${ }^{*}$ Corresponding author.

E-mail: alexandre.anesio@limnol.lu.se of dissolved organic matter mediates some of the transformation of organic carbon into inorganic forms.

Besides dissolved inorganic carbon (DIC), several low molecular weight organic molecules are produced upon exposure of DOM to UV irradiation. Examples of such compounds are acetaldehyde, acetate, acetone, citrate, formaldehyde, formate, glyoxalate, levulinate, malonate, methylglyoxal, oxalate, propanal, pyruvate (see review in Moran \& Zepp 1997). Irradiation of DOM has also been shown to stimulate subsequent bacterial growth on this material (Geller 1986, Lindell et al. 1995, Bertilsson et. al. 1999). 
UV irradiation of natural DOM may also produce highly reactive reduced oxygen species, among which hydrogen peroxide is the most abundant because of its relatively long turnover time in natural waters (Lean 1998). There may also be counteractive radiationdriven mechanisms that decrease the biodegradability of certain fractions of the total DOM (Keil \& Kirchman 1994). A third mechanism that may affect the bioavailability of total DOM is the direct photooxidation of labile compounds into inorganic forms. Bertilsson \& Tranvik (1998) demonstrated, using ${ }^{14} \mathrm{C}$-labeled tracers, that oxalic acid (a photoproduced low molecular weight carboxylic acid) could rapidly be further photooxidized into $\mathrm{CO}_{2}$. On the other hand, no further photooxidation was detected for the other organic acids tested by the authors (malonic, formic and acetic acid). In conclusion, the effects of UV radiation on bacterial growth are variable and occur at the same time in natural ecosystems. Furthermore, phototransformations of DOM occurring at the surface of lakes and oceans can most likely lead to both an increased and a decreased pool of substrates available for bacterial growth, and the net outcome might be related to the initial source and characteristics of bulk DOM (Anesio et al. 1999, Bertilsson 1999). These photochemical transformations might have a profound influence on the carbon flux in aquatic systems.

The higher concentration of DOM in freshwater systems, compared to marine waters, results from a higher primary production, often associated with aquatic macrophytes (Wetzel 1992). DOM from these plants can enter aquatic ecosystems through the excretion of photosynthates or through the leaching of plant material (Mann \& Wetzel 1996). Leachates from aquatic macrophytes are considered a substantial source of DOM to many inland waters (Wetzel 1992), but few studies have addressed the effects of solar UV radiation on these leachates. Wetzel et al. (1995) examined the photolysis of recalcitrant DOM leached from Juncus effusus and Typha latifolia and observed only subtle changes in bulk DOM. However, there was a substantial production of several low molecular weight organic acids and the radiation treatment also resulted in a slight stimulation of bacterial growth, relative to growth on dark-treated leachates. On the other hand, Anesio et al. (1999) observed an inhibition of bacterial growth on Phragmites australis leachates after exposure to UV radiation.

Despite a substantial increase in studies related to solar UV effects on DOM transformations, there is relatively little information about the influence of exposure time or amount of irradiated energy received by the DOM on transformations of DOM bulk. In this study, we evaluated the influence of the duration of artificial UV irradiation on abiotic transformations of leachates from 2 aquatic macrophytes: Phragmites australis and Hydrocaris morsus-ranae. In addition, we assessed the influence of these DOM phototransformations on bacterial growth.

\section{MATERIAL AND METHODS}

Experimental design. Dead leaves of Phragmites australis (Cav.) Trin. ex Steudel were collected in Lake Krankesjön (southern Sweden) in March 1996. Leaves were dried at room temperature and stored until the experiment. Senescent leaves of Hydrocaris morsusranae L. were collected in River Kävlinge (southern Sweden) in October 1998, and washed with deionized water. Macrophyte leaves were soaked in Milli-Q water in a refrigerator for $48 \mathrm{~h}$ (Anesio et al. 2000). DOM leached from the leaves was then filtered through a GF/F filter (Whatman). The filtrate was diluted with Milli-Q water to a final concentration of $10 \mathrm{mg} \mathrm{C}^{-1}$. Immediately before the start of UV exposure, the diluted leachate solutions were filtered through VacuCap $^{\mathrm{TM}}$ sterile filters $(0.2 \mu \mathrm{m}$, Gelman Sciences).

Leachate from each plant was poured into 56 quartz tubes (28 larger tubes of $190 \mathrm{ml}$ and 28 smaller tubes of $40 \mathrm{ml}$ ). The tubes were incubated at $22^{\circ} \mathrm{C}$ in a temperature-controlled room. Quadruplicates of both sizes of tubes were irradiated with artificial UVA + UVB radiation for $0,5,10,24,48,72$ and $120 \mathrm{~h}$. Controls consisted of leachates in 56 Pyrex glass tubes (28 tubes of $190 \mathrm{ml}$ and 28 tubes of $40 \mathrm{ml}$ ) kept in the dark. Dark treatments were achieved by wrapping the tubes with aluminum foil. The UV radiation source consisted of $8 \mathrm{flu}-$ orescent tubes (UVA-340, Q-Panel Co., USA) emitting UVA $\left(11.4 \mathrm{~W} \mathrm{~m}^{-2}\right), \mathrm{UVB}\left(1.09 \mathrm{~W} \mathrm{~m}^{-2}\right)$, and negligible amounts of PAR $\left(<5 \mathrm{~W} \mathrm{~m}^{-2}\right)$. After $120 \mathrm{~h}$, the total amount of energy received externally by the tubes corresponded to $\sim 5670 \mathrm{KJ} \mathrm{m}^{-2}$. After incubation, DIC, DOC, hydrogen peroxide concentration and absorbance at 250, 365 and $430 \mathrm{~nm}$ were measured in the leachates incubated in the larger tubes. Approximately $20 \mathrm{ml}$ from each tube were collected in acid rinsed plastic vials for analysis of oxalic, malonic, formic and acetic acids. Samples of each tube were also fixed with formalin (final concentration, $3.7 \%$ ) in $8 \mathrm{ml}$ sterile plastic vials to check for possible bacterial contamination. Tubes with bacterial numbers higher than $10^{5}$ cells $\mathrm{ml}^{-2}$ were discarded. Incubations were started at different times, so that all exposures were terminated simultaneously.

After UV irradiation/dark treatment, each tube was inoculated with bacteria ( $5 \%$ final concentration of inoculum). The inoculum was prepared by filtering water from a pond through a GF/F filter to avoid flagellate contamination. Together with the inoculum, 
nitrogen $\left(\mathrm{NH}_{4} \mathrm{NO}_{3}\right.$, final concentration $\left.50 \mu \mathrm{M} \mathrm{N}\right)$ and phosphorus $\left(\mathrm{KH}_{2} \mathrm{PO}_{4}\right.$, final concentration $\left.5 \mu \mathrm{M} \mathrm{P}\right)$ were added to each tube to ensure that bacteria would not be limited by $\mathrm{N}$ or $\mathrm{P}$. Tubes were incubated at $22^{\circ} \mathrm{C}$ in a temperature-controlled room in dark conditions. After 48, 72 and $96 \mathrm{~h}$, samples from each of the $190 \mathrm{ml}$ tubes were fixed with formalin in $8 \mathrm{ml}$ sterile plastic vials for bacterial counts. At $96 \mathrm{~h}, \mathrm{DIC}$, as an index of bacterial respiration, was measured in the $40 \mathrm{ml}$ tubes. These tubes had no headspace during the incubation. Therefore, we could measure bacterial respiration as DIC accumulation. For all tubes, initial DIC concentrations were subtracted from bacterial respiration.

Analytical procedures. DOC measurements were made by Pt-catalyzed, high-temperature combustion using a Shimadzu TOC-5000 total carbon analyzer, equipped with an ASI-5000 auto sampler. Inorganic carbon was removed by sparging with $\mathrm{CO}_{2}$-free air for 5 min after acidifying the sample with $\mathrm{HCl}$ (2 $\mathrm{M}$, final $\mathrm{pH} \sim 2$ ). For each tube, at least 3 replicate injections were made, resulting in a coefficient of variation of less than $2 \%$ (Granéli et al. 1996). Photooxidation was analyzed through measurements of DIC production. The water for DIC measurements was injected from the bottom of each quartz tube through Teflon tubing directly into the IC-port of the Shimadzu TOC-5000 total carbon analyzer. DIC analyses were done immediately after irradiation (photooxidation measurements) and after the incubation with bacteria was finished (respiration). For each sample, a minimum of 3 replicate injections was made, resulting in a CV of less than $2 \%$.

Absorbance measurements were done as an indication of photochemical transformations of DOM. Absorbance was measured at $430 \mathrm{~nm}$ (water color), and at 365 and $250 \mathrm{~nm}$, using a Beckman DU ${ }^{\circledR} 650$ spectrophotometer.

Hydrogen peroxide concentrations were measured as described in Tranvik \& Kokalj (1998). A working solution was prepared by mixing $25 \mu \mathrm{l}$ of N-acetyl-3, 7dihydroxyphenoxanine ( $1 \mathrm{mg}$ in $1 \mathrm{ml}$ of DMSO), $1 \mathrm{ml}$ of Milli-Q water and $2 \mathrm{ml}$ of horse radish peroxidase (Sigma Type VI, 50 units $\mathrm{ml}^{-1}$ in a $0.25 \mathrm{M}$ Tris buffer, $\mathrm{pH}$ 7.2). Immediately after irradiation, $30 \mu \mathrm{l}$ of the working solution were added to a $1 \mathrm{ml}$ sample. After ca 5 min, fluorescence was measured on a Shimadzu RF1501 spectrofluorometer, with excitation at $570 \mathrm{~nm}$ and emission at $585 \mathrm{~nm}$.

Carboxylic acids were measured using capillary electrophoresis (Bertilsson \& Tranvik 1998). Briefly, samples were spiked with a concentrated internal standard solution (molybdate) and octanesulfonate was added to a final concentration of $70 \mu \mathrm{M}$. A Quanta 4000 capillary electrophoresis system (Millipore) equipped with an $80 \mathrm{~cm}$ fused silica capillary with an inner diameter of $75 \mu \mathrm{m}$ was used for the analysis.
Samples were injected by a 45 s electromigrative preconcentration at $5 \mathrm{kV}$. The mobile phase was a $5 \mathrm{mM}$ 1,2,4,-Benzene tri-carboxylic acid buffer ( $\mathrm{pH} 8.0)$ with $0.5 \mathrm{mM}$ of an electroosmotic flow modifier (OFM-BT, Waters). A separation voltage of $15 \mathrm{kV}$ was applied with the anode located at the capillary outlet on the detector side. Detection of carboxylic acids was accomplished by universal indirect UV detection at $254 \mathrm{~nm}$. Standard curves and peak identifications were accomplished by spiking selected samples with small volumes of concentrated carboxylic acid stock solutions.

Bacterial abundance was measured using a Becton Dickinson FACSort flow-cytometer according to methodology proposed by del Giorgio et al. (1996). Syto 13 stain (50 $\mathrm{MM}$ final concentration, Molecular Probes) and Fluoresbrite ${ }^{\mathrm{TM}}$ Carboxy YG Microspheres $\left(\varnothing=1.58 \mu \mathrm{m}\right.$, ca $3 \times 10^{5} \mathrm{ml}^{-1}$ final concentration, Polysciences) were added to $1 \mathrm{ml}$ subsamples. The cytometer was controlled with the CellQuest 1.2 software. Bacterial cells and microspheres were separated in a log-log scattergram of green fluorescence intensity (FL1) and side scatter (SSC). Samples were run for 1 min or until 10000 cells were counted. The concentration of bacteria in the samples was calculated using the microspheres as an internal standard. The concentration of added microspheres was analyzed by epifluorescence microscopy. Bacterial biomass was estimated by measuring bacterial biovolume in an epifluorescence microscope connected to a CCD-camera. Bacterial samples were previously stained with DAPI, according to Porter \& Feig (1980). Images were captured with the ImageGrabber-24 software (Neotech) and processed with IPLab Spectrum 3.1a software (Signal Analytics). At least 150 bacteria on 3 separate images were analyzed for each sample, and the cell volumes were calculated using the formula proposed

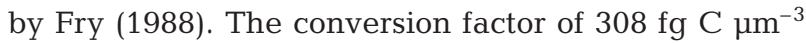
was used to convert the bacterial biovolume to bacterial biomass (Fry 1988).

Statistical analyses. Differences in abiotic variables, bacterial growth curves, biovolume, and respiration between UV and dark treatments were analyzed with ANOVA and $t$-tests using the SYSTAT software.

\section{RESULTS}

UV exposure time influenced the intensity of abiotic transformations of bulk DOM. In addition, we observed differences in DOM response to UV irradiation between Phragmites australis and Hydrocaris morsusranae leachates for the different exposure times. The rate of DIC accumulation for $P$. australis leachates was lower than for $H$. morsus-ranae, and the accumulation was linearly related to time $\left(y=0.0024 x+0.0413, \mathrm{R}^{2}=\right.$ 


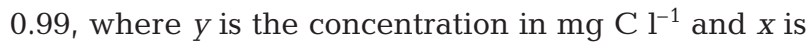
the time in hours) reaching $0.35 \mathrm{mg} \mathrm{C}^{-1}$ after $120 \mathrm{~h}$ of exposure. The accumulation of DIC from H. morsusranae leachate increased linearly up until $72 \mathrm{~h}$ of exposure $\left(y=0.0054 x+0.032, R^{2}=0.96\right)$, after which no further DIC production was observed (Fig. 1). Total production of DIC after $120 \mathrm{~h}$ was similar for both macrophyte leachates, accounting for approximately 3 to $4 \%$ of initial DOC. In dark treatments, there was no measurable DIC production. Decrease in absorbance was observed for both macrophyte leachates (Fig. 2). Absorbance fading was lowest at $250 \mathrm{~nm}$ and decreased with time of irradiation.

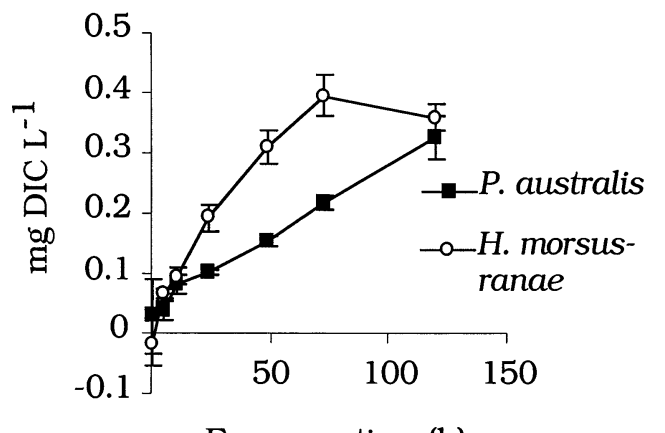

Exposure time (h)

Fig. 1. Photoproduction of dissolved inorganic carbon from leachates of Phragmites australis and Hydrocaris morsusranae as a function of irradiation time. Mean $\pm \mathrm{SD}, \mathrm{n}=4$

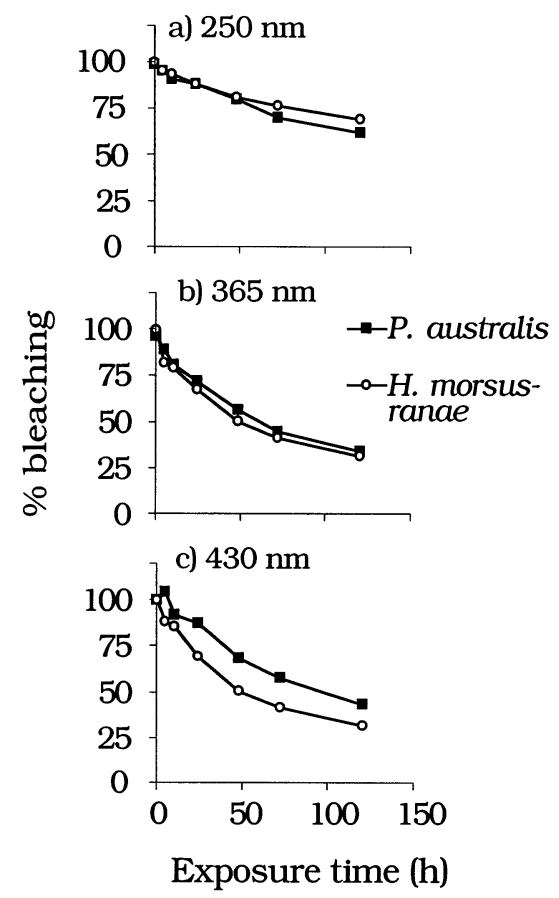

Fig. 2. Absorbance fading due to UV irradiation of Phragmites australis and Hydrocaris morsus-ranae leachates
After $120 \mathrm{~h}$ of UV exposure, the concentration of hydrogen peroxide was $8.5 \mu \mathrm{M}$ in Phragmites australis leachate and $2.0 \mu \mathrm{M}$ in Hydrocaris morsus-ranae leachate (Fig. 3). There was no production of peroxide in dark-treated leachates and background concentration was ca $0.02 \mu \mathrm{M} \mathrm{H}_{2} \mathrm{O}_{2}$. The concentration of hydrogen peroxide in $H$. morsus-ranae irradiated leachate reached a maximum of ca $4.0 \mu \mathrm{M}$ already after ca 10 to $24 \mathrm{~h}$ of exposure, and then decreased slightly. The concentration of hydrogen peroxide in $P$. australis leachate, increased continuously, and approached an asymptotic value of $8.5 \mu \mathrm{M}$.

The total concentration of the 4 carboxylic acids measured in this study was significantly higher in irradiated leachates after $72 \mathrm{~h}$ of UV exposure (the longest exposure time analyzed for carboxylic acids) compared to dark-treated leachates ( $p<0.01, t$-test). Prior to the irradiation treatment the total concentration of the 4 acids was around 5 times higher in Hydrocaris morsusranae leachate than in Phragmites australis leachate and constituted as much as $6.8 \%$ of total DOC. Some differences in the photoproduction of individual carboxylic acids were observed between $P$. australis and $H$. morsus-ranae leachates (Table 1). A general finding was that formic and acetic acid accumulated with increasing exposure time for both types of leachates, while oxalic acid decreased significantly during the irradiation. Still, particularly for $H$. morsus-ranae, there was also a substantial increase in the amount of carboxylic acids (primarily acetic acid) in the darkincubated leachates (Table 1). At the end of the incubation, acetic acid alone constituted close to $10 \%$ of total DOC in both dark-treated and irradiated leachates.

We analyzed the total accumulation of bacterial numbers in bioassay cultures. The growth curves all had similar shapes in the different incubations (i.e. an exponential growth phase and a stabilization of accumulating biomass in a plateau phase, Fig. 4). After $96 \mathrm{~h}$ of incubation, all cultures had reached the plateau

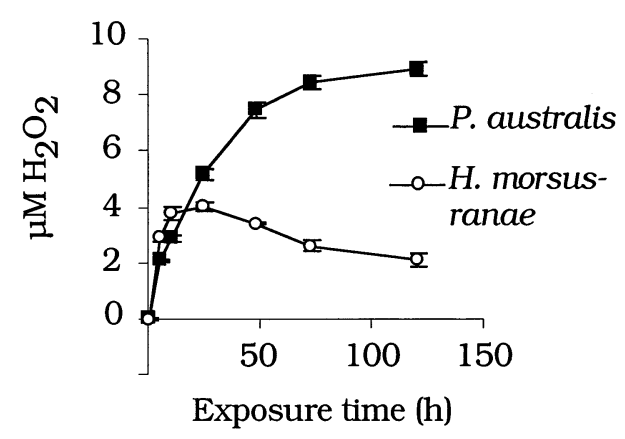

Fig. 3. Photoproduction of hydrogen peroxide from leachates of Phragmites australis and Hydrocaris morsus-ranae as a function of the irradiation time. Mean $\pm S D, n=4$ 
phase, and reported bacterial numbers at this point are therefore direct indicators of the total amount of easily available growth substrates, while bacterial numbers after $48 \mathrm{~h}$ of growth are probably more sensitive to initial inhibition of growth from hydrogen peroxide and other reactive species. For Phragmites australis, growth of bacteria at the end of the bacterial incubations (i.e. after $96 \mathrm{~h}$ ) was lower on all irradiated leachates compared to non-irradiated ones after irradiation times of $48 \mathrm{~h}$ and longer $(\mathrm{p}<0.05$, paired $t$-test; Fig. 5). For Hydrocaris morsus-ranae, the tendency of inhibition was less obvious (Figs. $4 \& 5$ ). No differences were found in individual biovolume of bacteria growing on irradiated or non-irradiated $P$. australis or $H$. morsus-ranae leachates ( $\mathrm{p}>0.1, t$-test). Hence, radiation-induced differences in bacterial biomass were directly related to bacterial numbers.

There were no significant differences in bacterial respiration between irradiated and non-irradiated Phragmites australis or Hydrocaris morsus-ranae leachates for most leachate exposure times. Exceptions were the $P$. australis leachates that were exposed for 72

\section{P. australis}
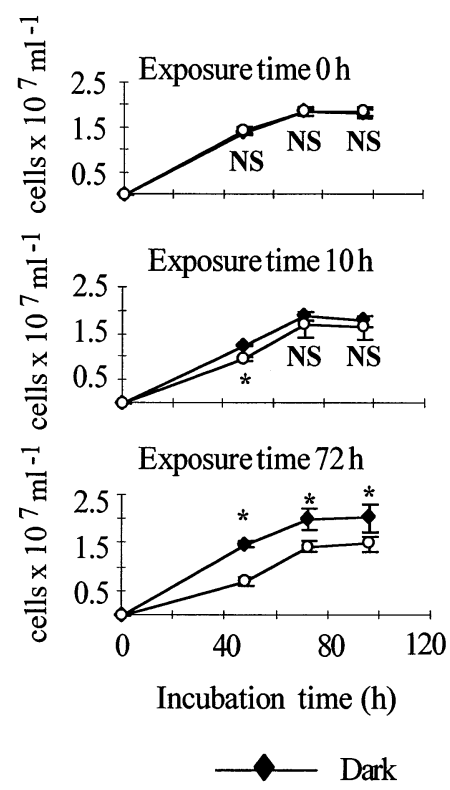

\section{H. morsus-ranae}
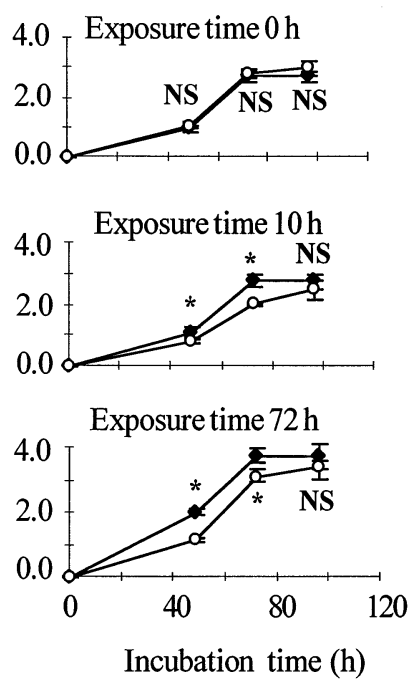

$\longrightarrow$ U UV
Fig. 4. Bacterial growth curves on the Phragmites australis and Hydrocaris morsus-ranae leachates which were exposed to UV radiation or kept in dark for 3 different times $(0,10$ and $72 \mathrm{~h}$ ). Mean $\pm \mathrm{SD}, \mathrm{n}=4$. NS is not significant and ${ }^{*}$ is $\mathrm{p}<0.05$ in paired $t$-tests and $120 \mathrm{~h}$ and the leachates of $H$. morsus-ranae that were exposed for $10 \mathrm{~h}$, where bacterial respiration was higher in the irradiated leachates.

Bacterial growth efficiency (BGE) was calculated from values of bacterial respiration and biomass accumulation. Bacterial carbon utilization (sum of respiration and biomass accumulation) appeared to be similar in UV-exposed leachates and dark controls. On the contrary, BGE was lower in irradiated leachates of Phragmites australis exposed for more than $48 \mathrm{~h}$ and in irradiated leachates of Hydrocaris morsusranae exposed for $10 \mathrm{~h}$ (Fig. 6) when compared to BGE in dark-treated leachates of both plant species.

\section{DISCUSSION}

\section{Leachate photoreactivity}

Photochemical transformations can be of significance for the removal of allochtonous DOM from the surface of lakes (Granéli et al. 1996) as well as in the ocean (Miller \& Zepp 1995). Photooxidation of organic material has been demonstrated in several studies and seems to be ubiquitous for all types of DOM. Hence, photooxidation does not only affect bulk DOM and dissolved humic matter in aquatic ecosystems, but also DOM derived from aquatic macrophytes as shown in the present study.

The amount of energy absorbed by DOM or the time of DOM exposure to UV radiation affects photoproduction of DIC. For both leachates tested in this study, DIC production rates were initially 


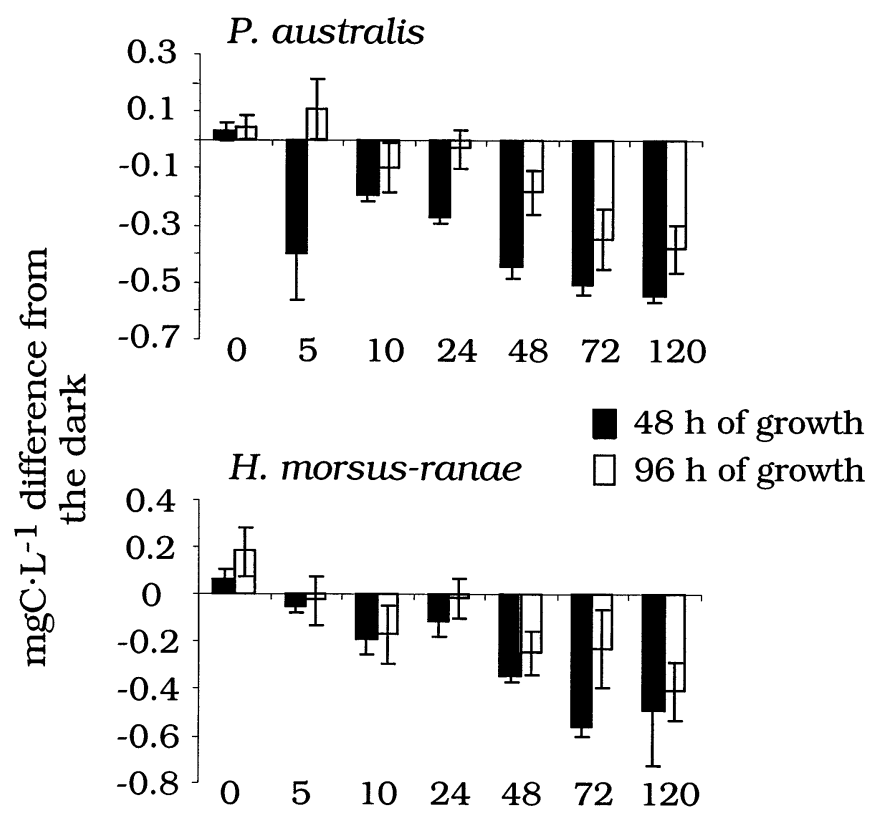

\section{Time of exposure (h)}

Fig. 5. Percentage of change of biomass on the Phragmites australis and Hydrocaris morsus-ranae leachates exposed to UV radiation in relation to the dark treatments. Bacterial biomass in dark treatments is $0.99 \mu \mathrm{g} \mathrm{C}^{-1}$ for $P$. australis and $1.80 \mu \mathrm{g} \mathrm{C} \mathrm{l}^{-1}$ for $H$. morsus-ranae leachates. Mean $\pm \mathrm{SD}, \mathrm{n}=4$

higher than after exposure times longer than $48 \mathrm{~h}$ (Table 2). Elevated initial DIC photoproduction may partly be due to a high initial absorbance that is subsequently reduced by bleaching during the irradiation, but may also indicate that some portion of the DOC is photolyzed rapidly, whereas the remainder undergoes a less efficient transformation (Miller \& Zepp 1995).

The differences in absorptivity probably also reflect differences in chemical composition between the 2 leachates, which in turn responds to radiation in different ways (see Table 1, Fig. 2). During the first $48 \mathrm{~h}$ of UV exposure, Hydrocaris morsus-ranae DOM was more easily photolyzed than Phragmites australis

Table 2. Chemical modifications by UV irradiation of leachates from Phragmites australis and Hydrocaris morsus-ranae

\begin{tabular}{|lccc|}
\hline & P. australis & $\begin{array}{c}\text { H. morsus- } \\
\text { ranae }\end{array}$ \\
\hline DIC production & $0-48 \mathrm{~h}$ & 3.3 & 6.5 \\
$\left(\mu \mathrm{C} \mathrm{l}^{-1} \mathrm{~h}^{-1}\right)$ & $48-120 \mathrm{~h}$ & 2.4 & 0.7 \\
$\mathrm{Hydrogen} \mathrm{peroxide}_{\text {production }\left(\mathrm{nM} \mathrm{h}^{-1}\right)}$ & $0-48 \mathrm{~h}$ & 157 & 72 \\
Absorbance fading & $48-120 \mathrm{~h}$ & 20 & -18 \\
$\left(250 \mathrm{~nm} \% ~^{-1}\right)$ & $48-48 \mathrm{~h}$ & 0.44 & 0.35 \\
& & 0.29 & 0.18 \\
\hline
\end{tabular}

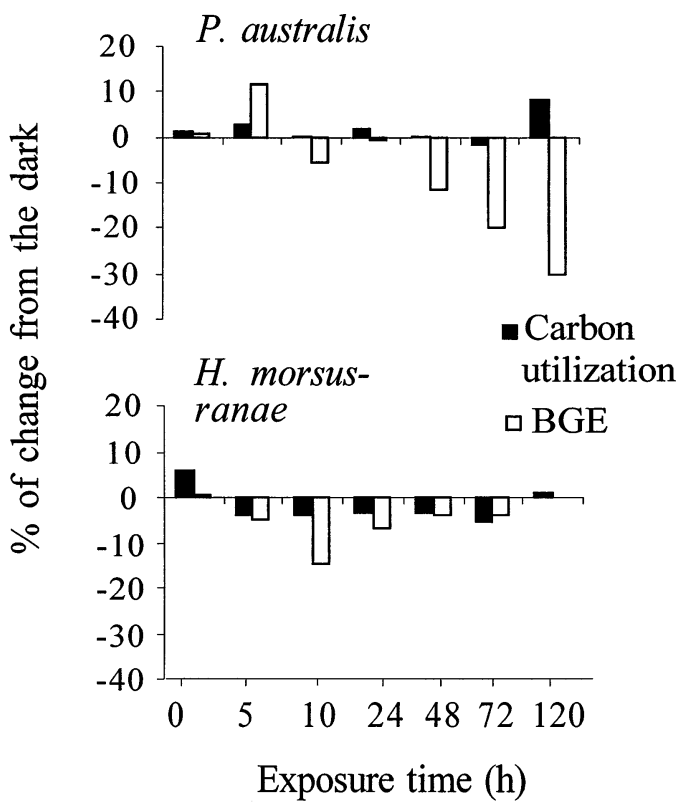

Fig. 6. Total carbon utilization and bacterial growth efficiency (BGE) of UV-treated leachates of Phragmites australis and Hydrocaris morsus-ranae as percentage of activities of darktreated leachates

DOM. On the other hand, further DIC production between 48 and $120 \mathrm{~h}$ was strongly reduced for $H$. morsus-ranae DOM, whereas DIC production was only slightly reduced for $P$. australis DOM (Table 2).

Hydrogen peroxide formation was higher for Hydrocaris morsus-ranae DOM during the first hours of irradiation, but then decreased relative to production from Phragmites australis DOM (see Fig. 3, Table 2). Based on the results of DIC and hydrogen peroxide rates of formation, it is thus reasonable to say that phototransformations of $H$. morsus-ranae DOM are initially more rapid than phototransformations of $P$. australis DOM. A better chemical characterization of leachates than that used in this and other studies is needed to determine the factors that influence photoreactivity of DOM. One such factor may be the oxygen concentration in the leachates. Oxygen availability can limit photooxidation of DOM (Lindell \& Rai 1994, Lindell et al. 2000), which may explain the decrease in the photoreactivity of $H$. morsus-ranae DOM with time. However, we previously measured abiotic oxygen consumption due to UV irradiation for several types of leachates, using identical radiation sources as in this study (data not shown). Oxygen concentrations decreased on average only $5 \%$ after $24 \mathrm{~h}$ exposure $(100 \%$ saturation at the beginning). Thus, it is not likely that oxygen should limit the photoreactions in $H$. morsus-ranae DOM already after $48 \mathrm{~h}$ of UV exposure. 
Differences in the bacterial availability of Phragmites australis and Hydrocaris morsus-ranae DOM were observed. H. morsus-ranae DOM had a much higher initial amount of low molecular weight (LMW) carboxylic acids and showed lower absorbance at $250 \mathrm{~nm}$ than DOM of $P$. australis. Based on bacterial growth curves obtained in the dark-treated leachates, H. morsus-ranae DOC supports more than 2-fold higher bacterial biomass per mg C, compared to $P$. australis DOC, which indicates that $H$. morsus-ranae DOC is more available to bacterial utilization than $P$. australis DOC (Fig. 4).

Many studies have compared photobleaching of DOM and DIC production from different types of water (Granéli et al. 1996, Bertilsson et al. 1999, Reche et al. 1999, Bertilsson \& Tranvik 2000). However, both the amount and quality of irradiation used in these studies varied, making comparisons between different studies difficult. Our study shows that different types of DOM can behave differently with respect to radiation, and that the amount of irradiation/length of incubation is important. Therefore, great care should be taken when photoreactivity of different types of water is compared. Labile DOM exposed to UV radiation during a short period can be highly reactive, while other fractions of DOM undergo less efficient transformations during longer exposures.

\section{Effects of UV radiation on leachate bioavailability}

Differences in the photoreactivity between Phragmites australis and Hydrocaris morsus-ranae DOM were also reflected in the bacterial response to phototransformed DOM, which, in general, was negative for both types of DOM. This conclusion is based on lower bacterial biomass production and lower BGE of UVtreated DOM. Photoproduction of bioavailable molecules (such as LMW carboxylic acids) is the common explanation for a net bacterial increase in UV-treated DOM batch cultures, compared to cultures based on dark-incubated DOM (Moran \& Zepp 1997, Bertilsson \& Tranvik 1998). A photochemically induced net decrease in bacterial growth can be explained by a photooxidation to DIC of bioavailable substrates (Bertilsson \& Tranvik 1998), production of inhibitory compounds (reviewed by Karentz et al. 1994) and/or formation of refractory material from labile components (Keil \& Kirchman 1994, Kieber et al. 1997, Tranvik \& Kokalj 1998).

DIC is a major photoproduct of DOM oxidation (Miller \& Zepp 1995, Moran \& Zepp 1997), and a reduction in bacterial production could be due to the loss of growth substrates that were photomineralized during UV exposure. Since bacterial substrates can be photochemically oxidized, it has been suggested that radiation and bacteria can compete for the same substrate (Benner \& Biddanda 1998). Bertilsson \& Tranvik (1998) demonstrated a photooxidation of oxalic acid, a photochemically produced LMW carboxylic acid. In agreement with their study, we found a photoinduced net decrease of oxalic acid with time in both types of DOM. However, we also observed a quantitatively dominant net accumulation of other LMW carboxylic acids, especially formic and acetic acids from Phragmites australis DOM and malonic, formic and acetic acids from Hydrocaris morsus-ranae DOM. It must be acknowledged that we only analyzed a limited number of LMW compounds while a wide range of other LMW compounds, including vitamins, may also be affected by photochemical processes.

Another probable explanation for a decrease in bacterial growth after UV irradiation of the leachates is photoproduction of refractory material from the labile fraction of DOM. Solar radiation has been identified as one of the causes of abiotic transformation of labile dissolved protein into more refractory compounds (Keil \& Kirchman 1994). The fact that most existing papers have shown a strong positive effect of UV irradiation on bioavailability of DOM does not contradict the current study. Most of the earlier studies have been performed in humic waters with a high content of highly aromatic and complex high molecular weight DOM, while there are only few studies performed using plant- or algae-derived DOC of more recent origin. Indeed, many of the latter studies have indicated that solar UV may actually decrease the bioavailability of the DOM (Benner \& Biddanda 1998, Tranvik \& Kokalj 1998, Anesio et al. 1999, 2000, Obernosterer et al. 1999). Photooxidation of unsaturated fatty acids (long chain carboxylic acids with hydrocarbons that have double or triple bonds) generates aldehydes and carbonyls on one of the chains, which in turn have a significant role in the formation of marine humic substances (Kieber et al. 1997). It should be noted that leachates are likely to be more available to bacteria than bulk DOM of a lake. The LMW DOM may then be partially degraded/condensed into refractory high molecular weight compounds by UV radiation. One way to demonstrate changes in DOM quality upon UV irradiation is through the absorptive characteristics of DOM. Fading of DOM absorption and changes in the relative absorbance at different wavelengths was observed upon UV irradiation. However, this information does not reveal if bioavailability increases or not. Additional information about the chemical composition of different types of DOM in different diagenetic stages is needed for a better understanding of the bacterial response to photochemical transformations of DOM. 
Bacterial production is greatly inhibited by high concentrations of peroxides in lake water (Xenopoulos \& Bird 1997). Highly reactive species, such as superoxide and hydroxyl radicals, can oxidize virtually any organic compound in the cell (Brock 1997). Hydrogen peroxide may for example react with iron to produce hydroxyl radicals $\left(\mathrm{OH}^{\bullet}\right)$, which are powerful oxidants (Scheck \& Frimmel 1995). Surface $\mathrm{H}_{2} \mathrm{O}_{2}$ concentration in aquatic ecosystems usually ranges from 11 to $350 \mathrm{nM}$ (Kieber \& Helz 1995). We detected high hydrogen peroxide production from both aquatic macrophyte leachates (Fig. 3). The impact of peroxide on bacteria in this study was expected to be severe due to the high peroxide concentrations, especially during the first hours after bacterial inoculation. However, it is not likely that high concentrations of hydrogen peroxide would be found in the end of bacterial incubations (i.e. after $120 \mathrm{~h}$ ), since hydrogen peroxide decay is fast. Tranvik \& Kokalj (1998) monitored both production and decay of hydrogen peroxide in UV-exposed DOM, using the same method to detect $\mathrm{H}_{2} \mathrm{O}_{2}$ as we used, and found that hydrogen peroxide had a half-life of about $5.5 \mathrm{~h}$. Bacterial growth curves in our experiments reached stationary phase of growth using both irradiated and non-irradiated leachates. Therefore, a negative impact of hydrogen peroxide would only cause a delay in the growth response of bacteria, but would not affect the final value. During the first $48 \mathrm{~h}$ after inoculation, bacterial biomass was lower in UV-irradiated DOM than in the dark-treated DOM for nearly all radiation time exposures. However, in some cases, bacterial biomass in cultures prepared from irradiated leachates did eventually reach similar levels as corresponding dark controls (Fig. 4). It is worth noting that the overall carbon utilization by bacteria was not significantly affected by UV irradiation of DOM from either leachate. However, BGE was significantly different between bacteria using dark-treated substrate and UV-irradiated DOM. Bacterial utilization of DOM from Phragmites australis UV irradiated for more than $48 \mathrm{~h}$ resulted in more substrate being diverted to respiration, relative to utilization of dark-treated DOM (Fig. 6). The lowest values of BGE coincided with the exposure time at which the highest concentrations of hydrogen peroxide were detected. The most likely explanation for the lower BGE in UV-treated exudates is the fact that the UV exposure typically results in the oxidation of organic compounds. The most commonly observed photoproducts (organic acids) are highly oxidized and, although they are readily available for bacterial utilization, the bacterial growth efficiency on such compounds is low compared to other more reduced compounds, for energetic reasons. This would be particularly pronounced if a large fraction of the more reduced photorectants are already LMW bio- available compounds such as amino acids, sugars, aldehydes etc. Lower BGE and higher bacterial respiration values in the UV-exposed leachates could also be due to DIC produced through the remaining peroxide in the water. Therefore, residual hydrogen peroxide could have resulted in the overestimation of the measured respiration. However, even if we assume (as a worst case) a 1:1 molar ratio of accumulated hydrogen peroxide to produced $\mathrm{CO}_{2}$, which is probably a substantial overestimation, this does not alter the obtained bacterial respiration.

\section{CONCLUSIONS}

UV radiation induced more intense phototransformations of Hydrocaris morsus-ranae leachates compared to Phragmites australis leachates. However, when UV exposure time was increased, phototransformations in $P$. australis DOM increased in proportion to exposure, while no additional changes could be detected in the $H$. morsus-ranae DOM upon further UV irradiation. Accordingly, the negative response of bacteria due to UV irradiation of DOM was more intense after a short exposure $(10 \mathrm{~h})$ of $H$. morsus-ranae leachate, while negative bacterial responses to irradiation of $P$. australis leachate were more intense after $48 \mathrm{~h}$ exposure. Aging of leachates might be the cause for lower bacterial growth on DOM subject to prolonged irradiation relative to dark controls. The same effect has also been described in Anesio et al. (1999). Further studies will be conducted to elucidate the exact role of photoproduced hydrogen peroxide on the aging of DOM. While the exposure to UV of leachates created presumably labile organic materials such as carboxylic acids, the bacterial assimilation of this liberated material was impacted by the simultaneous production of hydrogen peroxide, which acted to inhibit bacterial growth and prevent the utilization of the released compounds. A possible crossinteraction between hydrogen peroxide and photoproduced LMW DOM is a natural part of the total photoreactivity of the leachates and, probably, occurs under in situ conditions.

Acknowledgements. This research was supported by grants from the Swedish Foundation for International Cooperation in Research and Higher Education (STINT) to W.G., from the Brazilian Research Council (CNPq) to A.M.A. and from the Swedish Natural Science Research Council (NFR) to W.G. and S.B. We also thank Dr Lars Leonardson and 2 anonymous reviewers for valuable comments on the manuscript.

\section{LITERATURE CITED}

Anesio AM, Denward CMT, Tranvik LJ, Granéli W (1999) Decreased bacterial growth on vascular plant detritus due 
to photochemical modification. Aquat Microb Ecol 17: 159-165

Anesio AM, Thiel-Nielsen J. Granéli W (2000) Bacterial growth on photochemically transformed leachates from aquatic and terrestrial primary producers. Microb Ecol 40: 200-208

Benner R, Biddanda B (1998) Photochemical transformations of surface and deep marine dissolved organic matter: effects on bacterial growth. Limnol Oceanogr 43: 1373-1378

Bertilsson S (1999) Photochemical alterations of dissolved organic matter-impact on heterotrophic bacteria and carbon cycling in lakes. $\mathrm{PhD}$ thesis, Linköping studies in arts and science 197, Linköping University, Sweden

Bertilsson S, Tranvik LJ (1998) Photochemically produced carboxylic acids as substrates for freshwater bacterioplankton. Limnol Oceanogr 43:885-895

Bertilsson S, Tranvik LJ (2000) Photochemical transformation of dissolved organic matter in lakes. Limnol Oceanogr 45: 753-762

Bertilsson S, Stepanauskas R, Cuadros-Hansson R, Granéli W, Wikner J, Tranvik L (1999) Photochemically induced changes in bioavailable carbon and nitrogen pools in a boreal watershed. Aquat Microb Ecol 19:47-56

Brock TD (1997) Biology of microorganisms. In: Madigan MT, Martinko JM, Parker J (eds) Prentice Hall International Inc., New Jersey, p 174-175

Cole JJ (1999) Aquatic microbiology for ecosystem scientists: new and recycled paradigms in ecological microbiology. Ecosystems 2:215-225

del Giorgio P, Bird DF, Prairie YT, Planas D (1996) Flow cytometric determination of bacterial abundance in lake plankton with the green nucleic acid stain SYTO 13. Limnol Oceanogr 41:783-789

Fry JC (1988) Determination of biomass. In: Austin B (ed) Methods in aquatic bacteriology. John Wiley \& Sons, New York, p 27-72

Geller A (1986) Comparison of mechanisms enhancing biodegradability of refractory lake water constituints. Limnol Oceanogr 31:755-764

Granéli W, Lindell M, Tranvik L (1996) Photo-oxidative production of dissolved inorganic carbon in lakes of different humic content. Limnol Oceanogr 41:698-706

Karentz D, Bothwell ML, Coffin RB, Hanson A, Herndl GJ, Kilhan SS, Lesser MP, Lindell M, Moeller RE, Morris DP, Neale PJ, Sanders RW, Weiler CS, Wetzel RG (1994) Impact of UV-B radiation on pelagic freshwater ecosystems: report of working group on bacteria and phytoplankton. Arch Hydrobiol 43:31-69

Keil RG, Kirchman DL (1994) Abiotic transformation of labile protein to refractory protein in sea water. Mar Chem 45: 187-196

Kieber RJ, Helz GR (1995) Temporal and seasonal variations of hydrogen peroxide levels in estuarine waters. Estuar Coast Shelf Sci 40:495-503

Editorial responsibility: Patricia Glibert, Cambridge, Maryland, USA
Kieber RJ, Hydro LH, Seaton PJ (1997) Photooxidation of triglycerides and fatty acids in seawater: implication toward the formation of marine humic substances. Limnol Oceanogr 42:1454-1462

Lean D (1998) Attenuation of solar radiation in humic waters. In: Hessen DO, Tranvik LJ (eds) Aquatic humic substances - ecology and biogeochemistry. Ecological studies 133, Springer, Berlin, p 109-124

Lindell MJ, Rai H (1994) Photochemical oxygen consumption in humic waters. Arch Hydrobiol 43:145-155

Lindell M, Granéli W, Tranvik LJ (1995) Enhanced bacterial growth in response to photochemical transformation of dissolved organic matter. Limnol Oceanogr 40:195-199

Lindell MJ, Granéli W, Bertilsson S (2000) Seasonal photoreactivity of dissolved organic matter from lakes with contrasting humic contents. Can J Fish Aquat Sci 57: $875-885$

Mann CJ, Wetzel RG (1996) Loading and utilization of dissolved organic carbon from emergent macrophytes. Aquat Bot 53:61-72

Miller WL, Zepp RG (1995) Photochemical production of dissolved inorganic carbon from terrestrial organic matter: significance to the oceanic organic carbon cycle. Geophys Res Lett 22:417-420

Moran MA, Zepp RG (1997) Role of photoreactions in the formation of biologically labile compounds from dissolved organic matter. Limnol Oceanogr 42:1307-1316

Obernosterer I, Reitner B, Herndl GJ (1999) Contrasting effects of solar radiation on dissolved organic matter and its bioavailability to marine bacterioplankton. Limnol Oceanogr 44:1645-1654

Porter KG, Feig YS (1980) The use of DAPI for identifying and counting aquatic microflora. Limnol Oceanogr 25:943-948

Reche I, Pace ML, Cole JJ (1999) Relationship of trophic and chemical conditions to photobleaching of dissolved organic matter in lake ecosystems. Biogeochemistry 44: $259-280$

Scheck CK, Frimmel FH (1995) Degradation of phenol and salicylic acid by ultraviolet radiation/hydrogen peroxide/oxygen. Wat Res 29:2346-2352

Tranvik L, Kokalj S (1998) Decreased biodegradability of dissolved organic carbon of phytoplankton origin due to interactive effects of UV radiation and humic matter. Aquat Microb Ecol 14:301-307

Wetzel RG (1992) Gradient-dominant ecosystems: sources and regulatory functions of dissolved organic matter in freshwater ecosystems. Hydrobiologia 229:181-198

Wetzel RG, Hatcher PG, Bianchi TS (1995) Natural photolysis by ultraviolet irradiance of recalcitrant dissolved organic matter to simple substrates for rapid bacterial metabolism. Limnol Oceanogr 40:1369-1380

Xenopoulos MA, Bird DF (1997) Effects of acute exposure to hydrogen peroxide on the production of phytoplankton and bacterioplankton in a mesohumic lake. Photochem Photobiol 66:471-478

Submitted: July 19, 2000; Accepted: March 28, 2001

Proofs received from author(s): May 23, 2001 